\title{
FINANCIAL PERFORMANCE RANKING OF NATIONALIZED BANKS THROUGH INTEGRATED AHM-GRA-DEA METHOD
}

\author{
V.K. Viswanatha Raju \\ Part-time Ph.D. Scholar in Department of Mechanical Engineering, \\ College of Engineering (A), Andhra University, Visakhapatnam-3, India \\ VVS Kesava Rao \\ Professor, Department of Mechanical Engineering, College of Engineering (A) \\ Andhra University, Visakhapatnam-3, India
}

\begin{abstract}
In this paper an effort is made to rank the some of public sector banks in India basing on their financial soundness. In this work AHM methodology is applied to determine weightages of CAMEL ratios and after obtaining weightages Grey Relation analysis is applied to get Grey Relation coefficient and then these two are applied in Data Envelop Analysis to obtain ranks.
\end{abstract}

Keywords: AHM, CAMEL ratios, GRA, DEA.

Cite this Article: V.K. Viswanatha Raju and VVS Kesava Rao, Financial Performance Ranking of Nationalized Banks Through Integrated Ahm-Gra-Dea Method, International Journal of Management, 10 (3), 2019, pp. 15-35. http://iaeme.com/Home/issue/IJM?Volume=10\&Issue=3

\section{INTRODUCTION}

Performance evaluation of Banks is a major concern for the managers, shareholders, creditors, employees and customers, as strong banking system effects the growth and financial stability of the country. At the same time the banks must find a way to keep government regulators satisfied that their operating policies, loans, and investments are sound, protecting the public interest. The Indian banking sector has been the back bone of the Indian economy, helping it survives the various national and worldwide economic shocks and meltdowns.

To measure the financial position of each bank and manage it efficiently and effectively so many efforts have been made from time to time. In the process of continuous evaluation of the bank's financial performance the academicians, scholars and administrators have made several studies. However, with the Reserve Bank of India taking strong measures based on the recommendations of the Narasimhan committee, the land scope of Indian banking system changed together. All the banks were directed to follow the norms of capital adequacy, Asset quality, provisioning for Non-Performing Assets (NPAs), prudential norms, disclosure requirements, stream lining the processor's and complain with accounting standards, 
acceleration of pace and reach of latest technology and making financial statement transparent. Towards this end, they redefined their processes, methods, objectives, strategies, technologies and policies required to evaluate their financial position from period to period. For this purpose RBI suggested two supervisory rating models based on the recommendations made by Padmanabhan working group (1995) named CAMELS (Capital adequacy, Asset quality, Management capability, Earning quality, Liquidity and sensitivity), and CACS (Capital adequacy, Asset quality, Compliance, Systems and Control) for rating of Indian commercial banks and foreign banks operating in India . Further, different performance measurement tools and techniques have been developed in India as well as in other countries to evaluate the performance of banks. In performance evaluation of banking institutions, CAMEL rating is much popular among regulators due to its effectiveness in different countries including India. The CAMEL Criteria and the sub-criteria under each criterion is discussed below.

\section{CAMEL CRITERIA}

The performance of banks, both public and private, has been analyzed by academicians, scholars and administrators using CAMEL model in the last decade. The performance dimensions under CAMEL approach are Capital Adequacy (CA), Asset Quality (AQ), Management Efficiency (ME), Earning Quality (EQ) and Liquidity (LI) are considered in the study. Performance dimensions and their enables are briefly explained below.

\subsection{Capital Adequacy (CA)}

Capital base of financial institutions facilitates depositors in forming their risk perception about the organization. Also, it is important for financial managers to maintain adequate levels of capitalization. Capital adequacy is very useful for a bank to conserve \& protect stakeholders ${ }^{\text {ee }}$ confidence and prevent the bank from bankruptcy. For the study, the following ratios have been used to measure capital adequacy:

Capital adequacy ratio: Capital adequacy ratios ("CAR") are a measure of the amount of a bank's core capital expressed as a percentage of its risk-weighted asset. The capital adequacy ratio is developed to ensure that banks can absorb a reasonable level of losses occurred due to operational losses and determine the capacity of the bank in meeting the losses. As per the latest RBI norms, the banks should have a CAR of 9 per cent.

Advance to Assets Ratio (Advances/Assets): This is the ratio indicates a bank's aggressiveness in lending which ultimately results in better profitability.

Government Securities to Total Investments (G-sec/Investments): It is an important indicator showing the risk-taking ability of the bank. It is a bank's strategy to have high profits, high risk or low profits, low risk.

\subsection{Asset Quality (AQ)}

Asset quality determines the healthiness of financial institutions against loss of value in the assets as asset impairment risks the solvency of the financial institutions. The weakening value of assets has a spillover effect, as losses are eventually written-off against capital, which eventually expose the earning capacity of the institution. With this framework, the asset quality is assessed with respect to the level and severity of non-performing assets, adequacy of provisions, distribution of assets etc. For the study, the following ratios have been used to measure asset quality:

Net NPAs to Net Advances (NNPAs/NA): It is the most standard measure of assets quality measuring the net non-performing assets as a percentage to net advances.

Net NPAs to Total Assets (NNPAs/TA): This ratio discloses the efficiency of bank in assessing the credit risk and, to an extent, recovering the debts. 
Total Investments to Total Assets (TI/TA): It indicates the extent of deployment of assets in investment as against advances.

\subsection{Management Efficiency (ME)}

Management efficiency, another indispensable component of the CAMEL framework, means adherence to set norms, knack to plan and be proactive in the dynamic environment, leadership, innovativeness and administrative competence of the bank. The following ratios have been used to measure management efficiency.

Business per Employee: Business per employee shows the productivity of human force of bank. It is used as a tool to measure the efficiency of employees of a bank in generating business for the bank.

Profit per Employee: This shows the surplus earned per employee. It is known by dividing the profit after tax earned by the bank by the total number of employees.

Credit deposit ratio (ME3): It is the ratio of the total advances to deposits. It indicates the ability of a bank to convert its deposits into higher earning advances.

\subsection{Earning Quality (EQ)}

The quality of earnings represents the sustainability and growth of future earnings, value of a bank's lucrativeness and its competency to maintain quality and earn consistently. Earnings and profitability are examined as against interest rate policies and adequacy of provisioning. The single best indicator used to gauge earning is the Return on Assets (ROA), which is net income after taxes to total asset ratio. For the study, the following ratios have been used to measure earnings quality.

Return on assets: It is the ratio of Income to the assets. This ratio expresses the quality of income in form of income generated by core activities income.

NIM to total assets: NIM is the difference between the interest income and the interest expended. It is expressed as a percentage of total assets. A higher spread indicates better earnings, given the total assets.

Operating Profit to Total Assets Ratio (OPP/TA): This ratio indicates how much profit a bank can earn from its operations for every rupee invested in its total assets. It is the ratio between operating profits to total assets.

Interest income to total income: It is the ratio between interest incomes to total income.

\subsection{Liquidity (LI)}

In case of an adequate liquidity position, the institution can obtain sufficient funds, either by increasing liabilities or by converting its assets to cash quickly at a reasonable cost. The following ratios have been used to measure liquidity:

Liquid Assets to Total Assets (LA/TA): It measures the overall liquidity position of the bank. The liquid asset includes cash in hand, balance with institutions and money at call and short notice. The total assets include the revaluation of all the assets.

$G-S e c$ to Total Assets (G-Sec/TA): It measures the risk involved in the assets. This ratio measures the Government securities as proportionate to total assets.

Liquid Assets to Total Deposits (LA/TD): This ratio measures the liquidity available to the total deposits of the bank.

Liquid Assets to Demand Deposits (LA/DD): This ratio measures the ability of bank to meet the demand from depositors in a particular year. To offer higher liquidity for them, bank has to invest these funds in highly liquid form. 


\section{LITERATURE SURVEY}

Akbar Alem Tabriz, et al. (2014) [1] considered Fuzzy AHP and TOPSIS to accomplish, the more ideal level of performance evaluation and to reveal the ranking of branches and identify the ones taking leading positions in the market. In the study, financial ratios namely: Cash flow, return on assets, capital adequacy ratio, and demanding loss ratios are considered.

Zeliha Kaygisiz Ertuğ, et al. (2015) [2] developed an evaluation model that considers the quantitative and qualitative criteria for the appropriate selection of firms demanding commercial credit for both public and private banks. In this paper, the authors proposed an integrated model that combines the AHP and GRA into a single evaluation model. The model is illustrated with a case study.

Elham Shadkam, et al. (2015) [3] considered DEA, RSM and Cuckoo algorithm and presented a combinatory algorithm called DRC in which one response surface function for efficiency is obtained instead of a multi-response surface functions for each response. The proposed approach has been verified by using data from 40 active branches of Refah bank in Mashhad.

Dariush Akbarian (2015) [4] adopted cross efficiency and analytic hierarchy process (AHP) methods to evaluate the performance of 20 branch banks of Iran. In the first stage the crossefficiency value of each DMU is specified. In the second stage, the pairwise comparison matrix generated in the first stage is utilized to rank the scale of the units via the one-step process of AHP.

Mousa. G. A (2015) [5] examined the efficiency of the banking sector in the Bahrain Bourse using financial ratio analysis (FRA) and DEA. For FRA, the current study has used six ratios to evaluate three characteristics of banks' efficiency (Profitability; Liquidity and Risk). The findings have revealed that 2 banks are fully efficient in the period from 2009-10 to 2012-13).

Arora, et al. (2015) [6] made a study to find the performance of public banks in Turkey, from FYs 2004-05 to 2013-14, through an integrated model combining the AHP and the Operational Competitiveness Rating method (OCRA). The input and output weights were calculated by AHP while the efficiency of the banks was measured by OCRA.

Mehmet Ozcalici, et al. (2015) [7] adopted TOPSIS, fuzzy TOPSIS and GRA to forecast the rankings of return on the asset of the Turkish banking sector by utilizing dataset on financial indicators for the FY 2013-14.

Asmita Chitnis, et al. (2016) [8] proposed a unified approach based on DEA and TOPSIS to overcome the difficulty of unique ranking in the prevalent benchmarking and performance evaluation processes. The authors presented a case of an Indian bank to illustrate an application of the proposed approach.

Mohammad, et al. (2016) [9] identified the criteria and their coefficients used for financial performance evaluation of private banks using the fuzzy AHP method. After that, the authors evaluated financial performance of Iran private banks and ranked them using the information on the financial statements through TOPSIS method

Mehdi Fallah Jelodar (2016) [10] prioritized the factors affecting performance efficiency in the areas of management, personnel, finance, and customers using the methods of DEA and hierarchical analysis.

There are number of multi-criteria decision-making approaches like AHP, ANP, DEMATEL, TOPSIS etc are available in the literature are useful to evaluate the performance of banks. In the recent past, integrated approaches or hybrid models (SCOR-BSC, BSC-AHP, BSC-ISM-ANP, DEA - AHP model, Fuzzy AHP- Fuzzy TOPSIS, BSC-ANP-DEMATEL, Delphi method-AHP-TOPSIS, Dependence-based interval-valued ER (DIER)-BSC, 
DEMATEL- ANP- VIKOR) have also been proposed for performance measurement and analysis.

Data from 20 banks for a period of five years is collected and applied in the analysis.

\section{METHODOLOGY}

In the proposed method the relative weights of CAMEL criteria and their sub-criteria are obtained through AHM. Then the financial soundness of banks is evaluated and analyzed through integrated method of AHM-GRA-DEA method.

The methodology is explained in the following manner.

The AHM method is discussed below.

\subsection{The steps of AHM:}

Step-4.1: Though, CAMEL rating is much popular among regulators due to its effectiveness in different countries including India, this method could not import the weights to the performance dimensions/enablers to evaluate the financial soundness of Banks. In lieu of this, the relative weights of performance dimensions and their enablers need to be considered to evaluate the financial soundness of public sector banks.

In AHM, related matrix of attribute measures $\left(\mu_{i j}\right)$ are determined from pair wise comparison matrix $A=\left(a_{i j}\right)$ of AHP using the conversion equation as shown below.

$$
\mu_{i j}= \begin{cases}\frac{\beta k}{\beta k+1} & a_{i j}=k, a_{i j}>1 \\ \frac{1}{\beta k+1} & a_{i j}=\frac{1}{k}, a_{i j}<1 \\ 0.5 & a_{i j}=1, i \neq j \\ 0 & a_{i j}=1, i=j\end{cases}
$$

Relative attribute weight of the $j^{\text {th }}$ criterion $\left(W c_{j}\right)$ is obtained from the following relation.

$$
\begin{gathered}
W c_{j}=\frac{2}{J^{*}(j-1)} * \sum_{i=1}^{J} \mu_{i j} \quad j=1,2, \ldots, J \\
W c=\left[W c_{1}, W c_{2}, \ldots, W c_{J}\right]
\end{gathered}
$$

Step-4.2: Determining Grey Relational coefficient for entire 17 CAMEL ingredients for each bank.

\subsection{Grey Relation Analysis}

Grey relational analysis is a kind of method which enables determination of the relational degree of every factor in the system. The method can be used for systems that are incompletely described with relatively few data available, and for which standard statistical assumptions are not satisfied. Grey relation analysis quantifies all influences of various factors and their relations. It uses information from the Grey system to dynamically compare each factor quantitatively, based on the level of similarity and variability among factors to establish their relation. GRA analyzes the relational grade for discrete sequences. Let the number of the banks be $m$, and the number of the influence factors be $n$. Then a $m \times n$ value matrix is set up as shown in equation. 


$$
\mathrm{X}=\left[\begin{array}{l}
x_{1}(1), x_{1}(2), \ldots \ldots x_{1}(n) \\
x_{2}(1), x_{2}(2), \ldots x_{2}(n) \\
\ldots \\
\cdots \\
x_{m}(1), x_{m}(2), \ldots x_{m}(n)
\end{array}\right]
$$

where $x_{i}(j)$ is the value of $j^{\text {th }}$ influence factors of $i^{\text {th }}$ bank.

Step-4.2.1: Determination of Influence factors for each CAMEL ingredients.

Usually, two kinds of influence factors are included, they are:

1. Benefit - type factor (the bigger the better),

2. Cost - type (the smaller the better)

Benefit type:

$$
x s_{i}(j)=\frac{x_{i}(j)-\min x_{i}(j)}{\max x_{i}(j)-\min x(j)}
$$

Cost type:

$$
x s_{i}(j)=\frac{\min x_{i}(j)-x_{i}(j)}{\max x_{i}(j)-\min x(j)}
$$

where $x_{i}(j)$ is the reference value of $j^{\text {th }}$ enabler of $i^{\text {th }}$ bank.

For evaluating the financial performance 17 ratios are considered.

For normalizing banking financial ratios $1,2,3,7,8,9,10,11,12,13,14,15,16,17$ benefit type Eq.(1) is applied.

For normalizing banking financial ratios 4,5,6 cost type Eq.(2) is used.

Step-4.2.2: Determine absolute differences

The absolute difference in the compared series and the referential series should be obtained by using the following equation.

$$
\begin{aligned}
& \Delta x_{i}(j)=\left|x_{0}(j)-x s_{i}(j)\right| \\
& x_{0}(j)=\text { reference value of } j^{\text {th }} \text { enabler of } i^{\text {th }} \text { bank. }
\end{aligned}
$$

Step-4.2.3: Find out the maximum and minimum absolute differences.

The maximum $(\Delta \max )$ and the minimum $(\Delta \min )$ difference should be found from the absolute difference of the compared series and the referential series.

Step-4.2.4: Determine grey relation coefficient

In Grey relational analysis, Grey relational coefficient $\xi_{\text {can be expressed as shown in }}$ equation

$$
\xi_{i}(j)=\frac{\Delta \min +p \Delta \max }{\Delta x_{i}(j)+p \Delta \max }
$$

The distinguishing coefficient $p$ is between 0 and 1 . Generally, the distinguishing coefficient $p$ is set to 0.5 . 
Step-4.3: Using DEA based method determine ranking of the each bank.

\subsection{DEA Based GRA Model}

Data envelopment analysis, first proposed by Charnes, Cooper and Rhodes in 1978, based on the earlier work started by Farrell (1957) and developed by Banker (1984), is a mathematical technique developed in operations research and management science for measuring productive efficiency. The basic models of DEA are CCR (Charnes, Cooper, and Rhodes) BCC (Banker, Charnes and Cooper) additive and SBM.

Optimistic and pessimistic additive DEA models:

As all the grey relational coefficients are benefit (output) data, an optimistic additive DEA model for obtaining attribute weights in GRA can be developed like the additive model in Cooper et al (1999) without explicit inputs as follows:

$$
\begin{gathered}
P_{k}=\max \sum_{j=1}^{n} e_{j} s_{j}^{+} \\
\text {s.t. } \quad \sum_{j=1}^{n} \lambda_{i} \xi_{i j}-s_{j}^{+}=\xi_{k j} \forall j \\
\sum_{i=1}^{m} \lambda_{i}=1 \\
s_{j}^{+}, \lambda_{i} \geq 0
\end{gathered}
$$

where $1-P_{k}$ indicates the grey relational grade, $\Gamma_{h}(k=1,2, m)$, for alternative under assessment $A_{k}$ (known as a DMU in the DEA terminology) and $0 \leq P_{k} \leq 1 . s_{j}^{+}$is the slack variable of attribute $C_{j}(j=1,2, \ldots, n)$, expressing the difference between the performance of a composite alternative and the performance of the assessed alternative with respect to each attribute. In other words, $s_{j}^{+}$identifies a shortfall in the attribute value of $C_{j}$ for alternative $A_{k}$ Obviously, when $P_{k}=0$ alternative $A_{k}$ is considered as the best alternative in comparison to all the other alternatives, $e_{j}$ is the priority weight of attribute $C_{j}$ which is defined out of the internal mechanism of frontier for an additive model. The dual of equation (3) can be developed as follows:

$$
\begin{gathered}
\Gamma_{k}=\max \sum_{j=1}^{n} w_{j} \xi_{k j}-w_{0} \\
\text { s.t. } \quad \sum_{j=1}^{n} w_{j} \xi_{i j}-w_{0} \leq 1 \forall i \\
\mathrm{w}_{\mathrm{j}} \geq \mathrm{e}_{\mathrm{j}} \forall \mathrm{j} \\
w_{0} \text { free }
\end{gathered}
$$

This model is useful for our purpose in dealing with grey relational grades. The objective function in equation (4) maximizes the ratio of the grey relational grade of alternative $A_{k}$ to the maximum grey relational grade across all alternatives for the same set of weights $\left(\max \Gamma_{k} / \max \right.$ $\left.\Gamma_{i}\right)$, while the priority weights obtained by AHP impose the lower bounds on the attribute weights. Hence, an optimal set of weights in model priori information about the priorities of 
attributes, simultaneously. Finally, one should notice that the optimistic additive DEA models bounded by AHP does not necessarily yield results that are different from those obtained from the original additive DEA models (Charnes et al, 1985). In particular, it does not increase the power of discrimination between the considerable number of alternatives, which are usually ranked in the first place by obtaining the grey relational grades of 1 . To overcome these issues, we develop the additive models from the pessimistic point of view in which each alternative is assessed based on its distance from the worst practice frontier as follows:

$$
\begin{gathered}
P_{k}^{\prime}=\max \sum_{j=1}^{n} e_{j} s_{j}^{-} \\
\text {s.t. } \quad \sum_{i=1}^{m} \lambda_{i}^{\prime} \xi_{i j}+s_{j}^{-}=\xi_{k j} \forall j \\
\sum_{i=1}^{m} \lambda_{i}^{\prime}=1 \\
s_{j}^{-}, \lambda_{i}^{\prime} \geq 0
\end{gathered}
$$

Note that the only difference between equation (3) and equation (5) is the signs of slack variables in the first set of constraint, sf is the slack variable of attribute $\mathrm{Cfj}=1,2, \ldots, \ll)$, expressing the difference between the performance of the assessed alternative and the performance of a composite alternative with respect to each attribute. The dual model of equation (5) is shown below.

$$
\begin{array}{cc}
\Gamma_{k}^{\prime}=\max \sum_{j=1}^{n} w_{j}^{\prime} \xi_{k j}+w_{0}^{\prime} \\
\text { s.t. } \quad \sum_{j=1}^{n} w_{j}^{\prime} \xi_{i j}+w_{0}^{\prime} \geq 1 \forall i \\
w_{j}^{\prime} \geq e_{j} \forall j \\
w_{0}^{\prime} \text { free. }
\end{array}
$$

Here, we seek the worst weights in the sense that the objective function in equation (6) is minimized. The first set of constraints assures that the computed weights do not attain a grade smaller than 1. Each alternative is compared with these worst alternatives and is assessed based on the ratio of the distance from the worst-practice frontier. It is worth pointing out that the pessimistic additive models in this paper are not brand-new models in the DEA literature. Conceptually, it is parallel to the additive DEA models as discussed by Jahanshahloo and Afzalinejad (2006) for ranking alternatives on a full inefficient-frontier.

To combine the grey relational grades obtained equation (4) and (6), that is the best and worst sets of weights, the linear combination of corresponding normalized grades is recommended as follows (Zhou et al., 2007):

$$
\Delta_{k}(\beta)=\beta \frac{\Gamma_{k}-\Gamma_{\min }}{\Gamma_{\max }-\Gamma_{\min }}+(1-\beta) \frac{\Gamma_{k}^{\prime}-\Gamma_{\min }^{\prime}}{\Gamma_{\max }^{\prime}-\Gamma_{\min }^{\prime}}
$$


where $\Gamma_{\max }=\max \left\{\Gamma_{k}, k=1,2, \ldots, m\right\}, \Gamma_{\min }=\min \left\{\Gamma_{k}, k=1,2, \ldots, m\right\}, \Gamma_{\max }^{\prime}=\max \left\{\Gamma_{k}^{\prime}, k=\right.$ $1,2, \ldots, m\},\left\{\Gamma_{\min }^{\prime}=\min \left\{\Gamma_{k}^{\prime}, k=1,2, \ldots, m\right\}\right.$ and $0 \leq \beta \leq 1$ is an adjusting parameter, which may reflect the preference of a decision-maker on the best and worst sets of weights. $\Delta_{k}(\beta)$ is a normalized compromise grade in the range $[0,1]$.

Step-4.4: Determine Ranking of Banks

Banks are ranked basing on the descending order of normalized grey relation grade.

\section{MODEL CALCULATION FOR INTEGRATED AHM-GRA-DEA}

The banks are ranked for the five financial years based on integrated AHM-GRA-DEA method. The data shown in the Table-16 for the $1^{\text {st }}$ financial year is considered to evaluate the financial soundness. The model calculations are presented for the $1^{\text {st }}$ financial year.

\subsection{Relative weights of CAMEL criteria}

Relative weights of criteria are determined through AHM using pair wise comparison matrix. The pair-wise comparison is performed on the basis of how an element dominates the other and the judgments are entered using Saaty's 1-9 scale. The decision maker can express his preference between each pair of elements verbally as equally important, moderately more important, strongly more important, very strongly more important, and extremely more important. These descriptive preferences would then be translated into numerical values 1,3 , $5,7,9$, respectively, with 2, 4, 6, and 8 as intermediate values for comparisons between two successive judgments. Reciprocals of these values are used for the corresponding transposed judgments. Table-1 shows the comparison scale used by Saaty.

Table 1 Pair wise comparison scale (Saaty scale)

\begin{tabular}{|c|c|c|}
\hline $\begin{array}{c}\text { Intensity of } \\
\text { Importance }\end{array}$ & Definition & Explanation \\
\hline 1 & Equal importance & Two activities contribute equally to the objective \\
\hline 3 & Moderate importance & $\begin{array}{c}\text { Experience and judgment slightly favour one activity over } \\
\text { another }\end{array}$ \\
\hline 5 & Strong importance & $\begin{array}{c}\text { Experience and judgment very strongly over another, its } \\
\text { dominance demonstrated in practice }\end{array}$ \\
\hline 7 & Very strong importance & $\begin{array}{c}\text { An activity is favoured very strongly over another, } \\
\text { its dominance demonstrated in practice }\end{array}$ \\
\hline 9 & Extreme importance & $\begin{array}{c}\text { The evidence favouring one activity over another is } \\
\text { of the highest possible order of affirmation }\end{array}$ \\
\hline $2,4,6,8$ & $\begin{array}{c}\text { For compromise between the } \\
\text { above values }\end{array}$ & $\begin{array}{c}\text { Sometimes one needs to interpolate a compromise } \\
\text { judgment numerically because there is no good word to } \\
\text { describe it }\end{array}$ \\
\hline
\end{tabular}

Pair wise comparison matrix of criteria is formulated by the discussions with the process experts of the organization. Pair wise comparison matrix of CAMEL parameters is obtained as shown below.

Table 2 Pair wise comparison matrix

\begin{tabular}{|c|c|c|c|c|c|}
\hline & CA & AQ & ME & EQ & LI \\
\hline CA & 1.0000 & 0.1429 & 0.1111 & 0.2000 & 0.3333 \\
\hline AQ & 7.0000 & 1.0000 & 0.3333 & 3.0000 & 5.0000 \\
\hline ME & 9.0000 & 3.0000 & 1.0000 & 5.0000 & 7.0000 \\
\hline EQ & 5.0000 & 0.3333 & 0.2000 & 1.0000 & 3.0000 \\
\hline LI & 3.0000 & 0.2000 & 0.1429 & 0.3333 & 1.0000 \\
\hline
\end{tabular}




\section{Comparison judgement matrix}

$$
\mu_{i j}= \begin{cases}\frac{\beta k}{\beta k+1} & a_{i j}=k, a_{i j}>1 \\ \frac{1}{\beta k+1} & a_{i j}=\frac{1}{k}, a_{i j}<1 \\ 0.5 & a_{i j}=1, i \neq j \\ 0 & a_{i j}=1, i=j\end{cases}
$$

\section{Model calculation:}

For $i=, j=1 ; a_{i j}=1.00$; Then $\mu_{i j}=0.000$;

For $i=2, j=1 ; a_{i j}=k=7.00(>1)$; Then $\mu_{i j}=\frac{\beta k}{\beta k+1}$;

So $\mu_{i j}=(2 * 7.00) /(2 * 7.00+1)=14 / 15=0.9333$;

For $i=1, j=3 ; a_{i j}=1 / k=0.1111(<1)$ or $k=1 / 0.111=9$. Then $\mu_{i j}=\frac{\beta k}{\beta k+1}$;

So $\mu_{i j}=(1) /(2 * 9+1)=1 / 19=0.05263$.

Table 3 CAMEL criteria relative values

\begin{tabular}{|c|c|c|c|c|c|}
\hline & CA & AQ & ME & EQ & LI \\
\hline CA & 0.00000 & 0.06667 & 0.05263 & 0.09091 & 0.14286 \\
\hline AQ & 0.93333 & 0.00000 & 0.14286 & 0.85714 & 0.90909 \\
\hline ME & 0.94737 & 0.85714 & 0.00000 & 0.90909 & 0.93333 \\
\hline EQ & 0.90909 & 0.14286 & 0.09091 & 0.00000 & 0.85714 \\
\hline LI & 0.85714 & 0.09091 & 0.06667 & 0.14286 & 0.00000 \\
\hline
\end{tabular}

Relative weights of CAMEL criteria are obtained through AHM method using pair wise comparison matrix of criteria and are shown in the following Table-4.

Table 4 Final CAMEL criteria weights

\begin{tabular}{|c|c|c|c|c|c|}
\hline CAMEL Criteria & CA & AQ & ME & EQ & LI \\
\hline Relative weights & 0.0353 & 0.2842 & 0.3647 & 0.2000 & 0.1158 \\
\hline
\end{tabular}

From the Table-4, it is observed that the relative weight of Management Efficiency (ME) is 0.3647, which is higher compared to that of the other performance dimensions. Management Efficiency is a key to judge the decision making capacity of managing board. Variation in the management soundness ratios shows big variation among performance of banks. Asset quality (AQ) has the second priority of 0.2842 . The quality of assets is an important parameter to gauge the strength of a bank to determine the employment of assets in investment. The performance dimensions such as earning quality (EQ), Liquidity (LI) and Capital Adequacy (CA) have the next level priorities of $0.2000,0.1158$ and 0.0353 respectively. Earning quality mainly determines the profitability and productivity of the bank, explains the growth and sustainability in future earnings capacity. Liquidity indicates the position of the bank to meet immediate and long term financial needs with a quality investment asset. Capital Adequacy shows by and large financial condition of banks and also the capability of management to assemble the want for additional capital. 
These priority values of the performance dimensions form a basis for steps to improve the performance of the banks in terms of soundness. In the study, the respondents show high relative importance to Management soundness which is a key to judge the decision making capacity of managing board of banks.

\subsection{Relative weights of sub criteria under each CAMEL criterion}

\subsubsection{Capital Adequacy}

Pair wise comparison matrix of sub criteria of capital adequacy is formulated by the discussions with the process experts of the organization. Pair wise comparison matrix of capital adequacy sub-criteria is obtained as shown below.

Table 5 Sub criteria for capital adequacy

\begin{tabular}{|c|c|c|c|}
\hline Capital Adequacy & CA1 & CA2 & CA3 \\
\hline CA1 & 1 & 5 & 7 \\
\hline CA2 & $1 / 5$ & 1 & 5 \\
\hline CA3 & $1 / 7$ & $1 / 5$ & 1 \\
\hline
\end{tabular}

Table 6 Final capital adequacy sub criteria weights

\begin{tabular}{|c|c|c|c|}
\hline Capital Adequacy & CA1 & CA2 & CA3 \\
\hline Relative weights & 0.6141 & 0.3333 & 0.0526 \\
\hline
\end{tabular}

\subsubsection{Asset Quality}

Pair wise comparison matrix of sub criteria of Asset Quality is formulated by the discussions with the process experts of the organization. Pair wise comparison matrix of capital adequacy sub-criteria is obtained as shown below.

Table 7 Sub criteria for asset quality

\begin{tabular}{|c|c|c|c|}
\hline Asset Quality & AQ1 & AQ2 & AQ3 \\
\hline AQ1 & 1 & 2 & 3 \\
\hline AQ2 & $1 / 2$ & 1 & 2 \\
\hline AQ3 & $1 / 3$ & $1 / 2$ & 1 \\
\hline
\end{tabular}

Relative weights of Capital adequacy sub-criteria criteria are obtained through AHM method using pair wise comparison matrix of criteria and are shown in the following Table-8.

Table 8 Final asset quality sub criteria weights

\begin{tabular}{|c|c|c|c|}
\hline Asset Quality & AQ1 & AQ2 & AQ3 \\
\hline Relative weights & 0.5524 & 0.3333 & 0.1143 \\
\hline
\end{tabular}

\subsubsection{Management Efficiency}

Pair wise comparison matrix of sub criteria of management efficiency is formulated by the discussions with the process experts of the organization. Pair wise comparison matrix of capital adequacy sub-criteria is obtained as shown below. 
Table 9 Sub criteria for management efficiency

\begin{tabular}{|c|c|c|c|}
\hline Management Efficiency & ME1 & ME2 & ME3 \\
\hline ME1 & 1 & 2 & 4 \\
\hline ME2 & $1 / 2$ & 1 & 3 \\
\hline ME3 & $1 / 4$ & $1 / 3$ & 1 \\
\hline
\end{tabular}

Relative weights of management efficiency sub-criteria criteria are obtained through AHM method using pair wise comparison matrix of criteria and are shown in the following Table- 10.

Table 10 Final management efficiency sub criteria weights

\begin{tabular}{|c|c|c|c|}
\hline Management Efficiency & ME1 & ME2 & ME3 \\
\hline Relative weights & 0.5630 & 0.3524 & 0.0846 \\
\hline
\end{tabular}

\subsubsection{Earning Qualit:}

Pair wise comparison matrix of sub criteria of earning quality is formulated by the discussions with the process experts of the organization. Pair wise comparison matrix of earning quality sub-criteria is obtained as shown below.

Table 11 Sub criteria for earning quality

\begin{tabular}{|c|c|c|c|c|}
\hline Earning Quality & EQ1 & EQ2 & EQ3 & EQ4 \\
\hline EQ1 & 1 & 3 & 4 & 6 \\
\hline EQ2 & $1 / 3$ & 1 & 3 & 4 \\
\hline EQ3 & $1 / 4$ & $1 / 3$ & 1 & 3 \\
\hline EQ4 & $1 / 6$ & $1 / 4$ & $1 / 3$ & 1 \\
\hline
\end{tabular}

Relative weights of earning quality sub-criteria criteria are obtained through AHM method using pair wise comparison matrix of criteria and are shown in the following Table- 12.

Table 12 Final earning quality sub criteria weights

\begin{tabular}{|c|c|c|c|c|}
\hline Earning Quality & EQ1 & EQ2 & EQ3 & EQ4 \\
\hline Relative weights & 0.4448 & 0.3148 & 0.1852 & 0.0552 \\
\hline
\end{tabular}

\subsubsection{Liquidity}

Pair wise comparison matrix of sub criteria of liquidity is formulated by the discussions with the process experts of the organization. Pair wise comparison matrix of earning quality subcriteria is obtained as shown below.

Table 13 Sub criteria for liquidity

\begin{tabular}{|c|c|c|c|c|}
\hline Liquidity & LI1 & LI2 & LI3 & LI4 \\
\hline LI1 & 1 & 5 & 7 & 9 \\
\hline LI2 & $1 / 5$ & 1 & 6 & 8 \\
\hline LI3 & $1 / 7$ & $1 / 6$ & 1 & 6 \\
\hline LI4 & $1 / 9$ & $1 / 8$ & $1 / 6$ & 1 \\
\hline
\end{tabular}

Relative weights of liquidity sub-criteria criteria are obtained through AHM method using pair wise comparison matrix of criteria and are shown in the following Table-14. 
Financial Performance Ranking of Nationalized Banks Through Integrated Ahm-Gra-Dea Method

Table 14 Final liquidity sub criteria weights

\begin{tabular}{|c|c|c|c|c|}
\hline Liquidity & LI1 & LI2 & LI3 & LI4 \\
\hline Relative weights & 0.4650 & 0.3259 & 0.1777 & 0.0314 \\
\hline
\end{tabular}

Global weights of the performance enablers are determined by multiplying the relative weight of the performance enabler with the weight of the respective dimension. Global weights of the performance enablers are shown in Table-15.

Table 15 Global weights of performance enablers

\begin{tabular}{|c|c|c|c|c|}
\hline $\begin{array}{l}\text { Performance } \\
\text { Dimension }\end{array}$ & Weight & Performance Enabler & Weight & $\begin{array}{l}\text { Global } \\
\text { Weight }\end{array}$ \\
\hline \multirow{3}{*}{$\begin{array}{c}\text { Capital Adequacy } \\
\text { (CA) }\end{array}$} & \multirow{3}{*}{0.0353} & Capital adequacy ratio & 0.6141 & 0.0217 \\
\hline & & Advances to assets & 0.3333 & 0.0118 \\
\hline & & Government securities to total investments & 0.0525 & 0.0019 \\
\hline \multirow{3}{*}{$\begin{array}{c}\text { Asset Quality } \\
\text { (AQ) }\end{array}$} & \multirow{3}{*}{0.2842} & Net NPA to Net Advance & 0.5524 & 0.1570 \\
\hline & & Net NPA to Total Assets & 0.3333 & 0.0947 \\
\hline & & Total Investments to Total Assets & 0.1143 & 0.0325 \\
\hline \multirow{3}{*}{$\begin{array}{c}\text { Management } \\
\text { Soundness } \\
(\mathrm{MS})\end{array}$} & \multirow{3}{*}{0.3647} & Business per employee & 0.5630 & 0.2053 \\
\hline & & Profit per employee & 0.3524 & 0.1285 \\
\hline & & Credit deposit ratio & 0.0847 & 0.0309 \\
\hline \multirow{4}{*}{$\begin{array}{l}\text { Earning Quality } \\
\text { (EQ) }\end{array}$} & \multirow{4}{*}{0.2000} & Return on assets & 0.4449 & 0.0890 \\
\hline & & NIM to total assets & 0.3148 & 0.0630 \\
\hline & & Operating profit to total assets & 0.1852 & 0.0370 \\
\hline & & Interest income to total income & 0.0551 & 0.0110 \\
\hline \multirow{4}{*}{$\begin{array}{l}\text { Liability } \\
\text { (LI) }\end{array}$} & \multirow{4}{*}{0.1158} & Liquid assets to total assets & 0.4650 & 0.0538 \\
\hline & & Government securities to total assets & 0.3259 & 0.0377 \\
\hline & & Liquid assets to total deposits & 0.1778 & 0.0206 \\
\hline & & Liquid assets to demand deposits & 0.0314 & 0.0036 \\
\hline
\end{tabular}

\subsection{Data on financial ratios}

The data on the financial ratios of the banks is obtained through annual reports, financial statements etc.

Table 16 Data on financial ratios for the $1^{\text {st }}$ financial year

\begin{tabular}{|c|c|c|c|c|c|c|c|c|c|c|c|c|c|c|c|}
\hline \multirow{2}{*}{ Banks } & \multicolumn{3}{|c|}{$\begin{array}{c}\text { Capital } \\
\text { Adequacy }\end{array}$} & \multicolumn{3}{|c|}{ Asset Quality } & \multicolumn{3}{|c|}{$\begin{array}{c}\text { Management } \\
\text { Efficiency }\end{array}$} & \multicolumn{3}{|c|}{ Earning Quality } & \multicolumn{3}{|c|}{ Liquidity } \\
\hline & CA1 & CA2 & CA3 & AQ1 & AQ2 & AQ3 & ME1 & ME2 & ME3 & EQ1 EQ2 & EQ3 & EQ4 & LI1 & LI2 & LI3 \\
\hline Bank 1 & 12.96 & 61.89 & 81.25 & 0.79 & 0.49 & 28.59 & 10.63 & 6.70 & 70.99 & 1.112 .23 & 2.02 & 88.93 & 5.22 & 23.23 & 5.99 \\
\hline Bank 2 & 14.38 & 65.60 & 93.87 & 0.38 & 0.25 & 22.23 & 11.65 & 9.00 & 77.52 & 1.362 .95 & 2.22 & 90.24 & 6.60 & 20.86 & 7.80 \\
\hline Bank 3 & 14.52 & 63.81 & 83.23 & 0.35 & 0.22 & 19.92 & 12.29 & 11.00 & 74.87 & 1.330 .87 & 1.95 & 88.62 & 5.54 & 16.58 & 6.50 \\
\hline Bank 4 & 12.17 & 60.68 & 80.71 & 0.91 & 0.55 & 24.45 & 12.84 & 6.20 & 71.30 & \begin{tabular}{|l|l|}
0.82 & 0.54 \\
\end{tabular} & 1.53 & 89.17 & 6.20 & 24.78 & 7.29 \\
\hline Bank 5 & 13.35 & 61.33 & 82.44 & 1.32 & 0.81 & 29.42 & 8.25 & 2.38 & 70.13 & \begin{tabular}{|l|l|}
0.47 & 3.69 \\
\end{tabular} & 1.12 & 91.29 & 5.03 & 24.26 & 5.75 \\
\hline Bank 6 & 15.38 & 62.89 & 85.07 & 1.10 & 0.69 & 24.90 & 11.99 & 9.76 & 72.00 & 1.420 .93 & 1.81 & 89.08 & 6.55 & 21.18 & 7.50 \\
\hline Bank 7 & 11.64 & 61.85 & 87.62 & 0.65 & 0.40 & 25.98 & 8.35 & 3.96 & 72.33 & \begin{tabular}{|l|l|}
0.70 & 1.58 \\
\end{tabular} & 1.24 & 92.33 & 6.71 & 22.77 & 7.85 \\
\hline Bank 8 & 14.11 & 60.52 & 64.65 & 0.46 & 0.28 & 30.28 & 15.73 & 10.92 & 74.39 & \begin{tabular}{|l|l|}
1.21 & 1.99 \\
\end{tabular} & 1.78 & 87.91 & 5.67 & 19.57 & 6.97 \\
\hline Bank 9 & 13.64 & 62.00 & 79.12 & 1.06 & 0.66 & 26.94 & 23.46 & 11.93 & 87.04 & \begin{tabular}{|l|l|}
0.73 & 8.29 \\
\end{tabular} & 1.64 & 89.64 & 7.72 & 21.32 & 10.84 \\
\hline Bank 10 & 13.56 & 61.82 & |75.67| & 0.53 & 0.33 & 28.58 & 9.30 & 8.88 & $\mid 71.12$ & $1.53|3.08|$ & $|2.70|$ & $|88.79|$ & 5.65 & 21.62 & 6.50 \\
\hline
\end{tabular}




\begin{tabular}{|c|c|c|c|c|c|c|c|c|c|c|c|c|c|c|c|}
\hline \multirow{2}{*}{ Banks } & \multicolumn{3}{|c|}{$\begin{array}{c}\text { Capital } \\
\text { Adequacy }\end{array}$} & \multicolumn{3}{|c|}{ Asset Quality } & \multicolumn{3}{|c|}{$\begin{array}{c}\text { Management } \\
\text { Efficiency }\end{array}$} & \multicolumn{3}{|c|}{ Earning Quality } & \multicolumn{3}{|c|}{ Liquidity } \\
\hline & CA1 & CA2 & CA3 & AQ1 & AQ2 & AQ3 & ME1 & ME2 & ME3 & EQ1 & EQ3 & EQ4 & LI1 & LI2 & LI3 \\
\hline Bank 11 & 14.55 & 62.55 & 98.17 & 1.19 & 0.74 & & 10.05 & 4.16 & 77.00 & \begin{tabular}{|l|l|l|}
0.71 & 1.74 \\
\end{tabular} & 1.60 & 90.81 & 5.60 & 26.69 & 6.89 \\
\hline Bank 12 & 14.23 & 59.44 & 73.87 & 0.98 & 0.58 & 30.71 & 14.18 & 9.04 & 68.97 & \begin{tabular}{|l|l|l|}
1.03 & 1.65 \\
\end{tabular} & 2.01 & 92.64 & 5.90 & 22.68 & 6.84 \\
\hline & 12.42 & 63.99 & 83.54 & 0.85 & 0.54 & & 10.18 & .35 & 77.38 & \begin{tabular}{|l|l|l}
1.34 & 1.05 \\
\end{tabular} & 2.39 & 88.19 & 6.28 & 21.01 & 7.60 \\
\hline Bar & & & & 0.83 & & & 7.51 & 5.00 & & \begin{tabular}{|l|l|l}
0.96 & 5.37 \\
\end{tabular} & 1.81 & 88.23 & 8.54 & 20.87 & 9.98 \\
\hline Bank 15 & 11.98 & 61.84 & 78.82 & 1.63 & 1.01 & 24.16 & 7.04 & 3.84 & 81.03 & 0.712 .71 & 2.07 & 83.72 & 17.30 & 42.69 & 22.66 \\
\hline Bank 16 & 12.54 & 64.87 & 80.11 & 0.98 & 0.64 & 25.26 & 8.88 & 8.00 & 79.17 & 1.123 .66 & 1.66 & 90.00 & 6.64 & 20.23 & 8.10 \\
\hline Bank 17 & 13.04 & 68.21 & 86.41 & 0.97 & 0.66 & 22.40 & 8.75 & 3.99 & 78.75 & 0.762 .17 & 1.76 & 92.60 & 6.67 & 19.36 & 7.70 \\
\hline Bank 18 & 13.71 & 60.63 & 83.69 & 1.84 & 1.12 & 26.27 & 10.69 & 4.19 & 68.19 & \begin{tabular}{|l|l|}
0.66 & 1.88 \\
\end{tabular} & 1.65 & 92.47 & 6.37 & 29.01 & 7.16 \\
\hline Bank 19 & 12.95 & 63.98 & 79.57 & 1.19 & 0.76 & 24.75 & 10.43 & 8.00 & 74.58 & $1.05 \quad 1.41$ & 1.82 & 88.97 & 7.46 & 22.37 & 8.70 \\
\hline Bank 20 & 13.05 & 59.42 & 72.83 & 1.42 & 0.84 & 29.16 & 8.60 & 3.48 & 68.73 & \begin{tabular}{|l|l|}
0.66 & 3.54 \\
\end{tabular} & 1.67 & 90.87 & 6.60 & 21.24 & 7.63 \\
\hline
\end{tabular}

\subsection{Normalized financial ratios}

Normalized Financial Ratios of the banks for the $1^{\text {st }}$ financial Year are calculated as discussed in methodology and are shown in the Table-17.

\section{Model calculation:}

For example for bank 1 and CA1:

CA1 is benefit criteria hence the following formula as discussed

$$
x s_{i}(j)=\frac{\left|x_{i}(j)-\min x_{i}(j)\right|}{\max x_{i}(j)-\min x(j)}
$$

Min of CA1 $=11.64 ;$ Max of CA1 $=15.38 ;$ CA1 of bank $1=12.96$

$$
=\frac{|12.96-11.64|}{15.38-11.64}=0.3529
$$

For example for bank 2 and AQ1:

AQ1 is cost criteria hence the following formula as discussed

$$
x s_{i}(j)=\frac{\max x_{i}(j)-x_{i}(j)}{\max x_{i}(j)-\min x(j)}
$$

Min of AQ1 = 0.35; Max of AQ1 = 1.84; AQ1 of bank $2=0.38$

$$
=\frac{|1.84-0.38|}{1.84-0.38}=0.9799
$$

\begin{tabular}{|c|c|c|c|c|c|c|c|c|c|c|c|c|c|c|c|c|c|}
\hline \multirow{2}{*}{ Banks } & \multicolumn{3}{|c|}{ CA } & \multicolumn{3}{|c|}{ AQ } & \multicolumn{3}{|c|}{ ME } & \multicolumn{4}{|c|}{ HQ } & \multicolumn{4}{|c|}{ LI } \\
\hline & CA1 & CA2 & CA3 & AQ1 & AQ2 & AQ3 & ME1 & ME2 & ME3 & EQ1 & EQ2 & EQ3 & EQ4 & LI1 & LI2 & LI3 & LI4 \\
\hline Bank 1 & 0.3529 & 0.2804 & 0.4954 & 0.7047 & 0.7030 & 0.1967 & 0.2186 & 0.4524 & 0.1483 & 0.6038 & 0.2186 & 0.5679 & 0.5844 & 0.0156 & 0.2545 & 0.0140 & 0.0199 \\
\hline Bank 2 & 0.7326 & 0.7023 & 0.8717 & 0.9799 & 0.9658 & 0.7863 & 0.2808 & 0.6932 & 0.4946 & 0.8396 & 0.3106 & 0.6920 & 0.7305 & 0.1277 & 0.1640 & 0.1208 & 0.4131 \\
\hline Bank 3 & 0.7701 & 0.4986 & 0.5544 & 1.0000 & 1.0000 & 1.0000 & 0.3197 & 0.9026 & 0.3541 & 0.8113 & 0.0425 & 0.5231 & 0.5496 & 0.0418 & 0.0000 & 0.0444 & 0.2725 \\
\hline Bank 4 & \begin{tabular}{|l|l|}
0.1417 \\
\end{tabular} & 0.1434 & 0.4793 & 0.6242 & 0.6281 & 0.5799 & 0.3532 & 0.4000 & 0.1646 & 0.3302 & 0.0000 & 0.2615 & 0.6108 & 0.0955 & 0.3141 & 0.0907 & 0.6930 \\
\hline Bank 5 & \begin{tabular}{|l|}
0.4572 \\
\end{tabular} & 0.2170 & 0.5308 & 0.3488 & 0.3426 & 0.1192 & 0.0737 & 0.0000 & 0.1029 & 0.0000 & 0.4064 & 0.0000 & 0.8483 & 0.0000 & 0.2939 & 0.0000 & 0.0040 \\
\hline Bank 6 & 1.0000 & 0.3943 & 0.6093 & 0.4948 & 0.4722 & 0.5388 & 0.3015 & 0.7728 & 0.2018 & 0.8962 & 0.0500 & 0.4381 & 0.6009 & 0.1241 & 0.1761 & 0.1034 & 0.3112 \\
\hline Bank 7 & 0.0000 & 0.2758 & 0.6854 & 0.7987 & 0.7956 & 0.4379 & 0.0798 & 0.1654 & 0.2194 & 0.2170 & 0.1339 & 0.0737 & 0.9646 & 0.1371 & 0.2370 & 0.1240 & 0.3248 \\
\hline Bank 9 & 0.6604 & 0.1250 & 0.0000 & 0.9262 & 0.9370 & 0.0398 & 0.5292 & 0.8942 & 0.3288 & 0.6981 & 0.1865 & \begin{tabular}{|l}
0.4169 \\
\end{tabular} & 0.4699 & 0.0524 & 0.1146 & 0.0722 & 0.0000 \\
\hline
\end{tabular}

Similarly, other values are calculated and shown in Table-17.

Table-17: Normalized financial ratios ( $1^{\text {st }}$ financial year) 
Financial Performance Ranking of Nationalized Banks Through Integrated Ahm-Gra-Dea Method

\begin{tabular}{|c|c|c|c|c|c|c|c|c|c|c|c|c|c|c|c|c|c|}
\hline \multirow{2}{*}{ Banks } & \multicolumn{3}{|c|}{ CA } & \multicolumn{3}{|c|}{$\mathbf{A Q}$} & \multicolumn{3}{|c|}{ ME } & \multicolumn{4}{|c|}{ HQ } & \multicolumn{4}{|c|}{ LI } \\
\hline & CA1 & $\mathrm{CA} 2$ & $\mathrm{CA} 3$ & AQ1 & $\mathrm{AQ} 2$ & $\mathrm{AQ} 3$ & ME1 & ME2 & ME3 & EQ1 & $\mathrm{EQ} 2$ & EQ3 & EQ4 & LI1 & LI2 & LI3 & LI4 \\
\hline Bank 9 & 0.5348 & 0.2935 & 0.4319 & 0.5235 & 0.5072 & 0.3490 & 1.0000 & 1.0000 & 1.0000 & 0.2453 & 1.0000 & 0.3294 & 0.6633 & 0.2192 & 0.1815 & 0.3006 & 0.2385 \\
\hline Bank 10 & 0.5134 & 0.2732 & 0.3288 & 0.8792 & 0.8822 & 0.1975 & 0.1376 & 0.6806 & 0.1553 & 1.0000 & 0.3278 & 1.0000 & 0.5681 & 0.0505 & 0.1931 & 0.0442 & 0.4761 \\
\hline Bank 11 & 0.7781 & 0.3561 & 1.0000 & 0.4362 & 0.4170 & 0.3262 & 0.1833 & 0.1864 & 0.4675 & 0.2264 & 0.1547 & 0.3036 & 0.7943 & .0463 & .3872 & 0.0674 & .2620 \\
\hline Bank 12 & 0.6925 & 0.0026 & 02752 & & 0.5973 & 0.00 & 48 & 0.6974 & 13 & & 430 & & 1.0000 & & 2338 & 0.0644 & 4220 \\
\hline Bank 13 & 0.2086 & 0.5201 & 0.5637 & 0.6644 & 0.6449 & 0.5149 & 1911 & 0.6251 & 0.4871 & \begin{tabular}{|l|l|}
0.8208 \\
\end{tabular} & 0.0653 & 0.8041 & \begin{tabular}{|l|l|}
0.5013 \\
\end{tabular} & 1022 & 0.1698 & 0.1091 & 0.2989 \\
\hline Bank 14 & 0.0107 & 0.6862 & 0.9700 & 0.6779 & 0.6411 & 0.8558 & 0.0286 & 0.2743 & 0.4416 & 0.4623 & 0.6232 & 0.4368 & 0.5056 & 0.2861 & 0.1642 & 02502 & 0.8980 \\
\hline Bank 15 & 0.0909 & 0.2748 & 0.4227 & 0.1409 & 0.1202 & 0.6074 & 0.0000 & 0.1529 & 0.6808 & 0.2264 & 0.2804 & 0.6002 & 0.0000 & 1.0000 & 1.0000 & 1.0000 & 0.1370 \\
\hline Bank 16 & 0.2406 & 0.6200 & 0.4613 & 0.5772 & 0.5371 & 0.5053 & 0.1121 & 0.5885 & 0.5824 & 0.6132 & 0.4030 & 0.3394 & 0.7033 & 0.1308 & 0.1399 & 0.1386 & 1.0000 \\
\hline & 3743 & 1.0000 & 0.6493 & 5839 & 0.5113 & 0.7700 & 0.1041 & 0.1686 & 0.5601 & 0.2736 & 0.2105 & 0.4024 & 0.9953 & 0.1337 & .1064 & 0.1152 & 0.3831 \\
\hline Bank 18 & 0.5535 & 0.1377 & 0.5681 & 0.0000 & 0.0000 & 0.4113 & 0.2223 & 0.1895 & 0.0000 & 0.1792 & 0.1727 & 0.3347 & 0.9812 & 0.1089 & 0.4760 & 0.0832 & 0.7561 \\
\hline Bank 19 & 0.3503 & 0.5186 & 0.4453 & 0.4362 & 0.3933 & 0.5526 & 0.2065 & 0.5885 & 0.3386 & \begin{tabular}{|l|l|}
0.5472 \\
\end{tabular} & 0.1123 & \begin{tabular}{|l|l|}
0.4450 \\
\end{tabular} & 0.5888 & 0.1982 & 0.2217 & 0.1741 & 0.3103 \\
\hline Bank 20 & 0.3770 & 0.0000 & \begin{tabular}{|l|}
02440 \\
\end{tabular} & 0.2819 & 0.3074 & 0.1432 & 0.0950 & 0.1152 & \begin{tabular}{|l|l|}
0.0284 \\
\end{tabular} & \begin{tabular}{|l|l|}
0.1792 \\
\end{tabular} & 0.3875 & \begin{tabular}{|l|}
0.3501 \\
\end{tabular} & 0.8015 & 0.1279 & 0.1784 & 0.1112 & 0.1150 \\
\hline
\end{tabular}

\section{Absolute differences}

The absolute difference in the compared series and the referential series should be obtained by using equation as discussed.

\section{Model calculation:}

\section{For bank 2 CA1}

The absolute difference in the compared series and the referential series is obtained using the following equation as discussed.

$$
\Delta x_{i}(j)=\left|x_{0}(j)-x s_{i}(j)\right|
$$

Reference series $=x_{0}(j)=1.0 ; x s_{i}(j)=0.7326($ from normalized data matrix $)$

$$
\Delta x_{i}(j)=|1.000-0.7326|=0.2674
$$

Similarly other values are calculated and the absolute differences are shown in Table- 18 .

\begin{tabular}{|c|c|c|c|c|c|c|c|c|c|c|c|c|c|c|c|c|c|}
\hline \multirow{2}{*}{ Bank } & \multicolumn{3}{|c|}{ CA } & \multicolumn{3}{|c|}{$\mathbf{A Q}$} & \multicolumn{3}{|c|}{ ME } & \multicolumn{4}{|c|}{ EQ } & \multicolumn{4}{|c|}{ LI } \\
\hline & CA1 & $\mathrm{CA} 2$ & $\mathrm{CA} 3$ & AQ1 & AQ2 & AQ3 & ME1 & ME2 & ME3 & EQ1 & EQ2 & EQ3 & EQ4 & LI1 & LI2 & LI3 & LI4 \\
\hline Bank 1 & 0.6471 & 0.7196 & 0.5046 & 0.2953 & 0.2970 & 0.8033 & 0.7814 & 0.5476 & 0.8517 & 0.3962 & 0.7814 & 0.4321 & 0.4156 & 0.9844 & 0.7455 & 0.9860 & 0.9801 \\
\hline Bank 2 & 0.2674 & 0.2977 & 0.1283 & 0.0201 & 0.0342 & 0.2137 & 0.7192 & 0.3068 & 0.5054 & 0.1604 & 0.6894 & 0.3080 & 0.2695 & 0.8723 & 0.8360 & 0.8792 & 0.5869 \\
\hline Bank 3 & 0.2299 & 0.5014 & 0.4456 & 0.0000 & 0.0000 & 0.0000 & 0.6803 & 0.0974 & 0.6459 & 0.1887 & 0.9575 & 0.4769 & 0.4504 & 0.9582 & 1.0000 & 0.9556 & 0.7275 \\
\hline Bank 4 & 0.8583 & 0.8566 & 0.5207 & 0.3758 & 0.3719 & 0.4201 & 0.6468 & 0.6000 & 0.8354 & 0.6698 & 1.0000 & 0.7385 & 0.3892 & 0.9045 & 0.6859 & 0.9093 & 0.3070 \\
\hline Bank 5 & 0.5428 & 0.7830 & 0.4692 & 0.6512 & 0.6574 & 0.8808 & 0.9263 & 1.0000 & 0.8971 & 1.0000 & 0.5936 & 1.0000 & 0.1517 & 1.0000 & 0.7061 & 1.0000 & 0.9960 \\
\hline Bank 6 & 0.0000 & 0.6057 & 0.3907 & 0.5052 & 0.5278 & 0.4612 & 0.6985 & 0.2272 & 0.7982 & 0.1038 & 0.9500 & 0.5619 & 0.3991 & 0.8759 & 0.8239 & 0.8966 & 0.6888 \\
\hline Bank 7 & 1.0000 & 0.7242 & 0.3146 & 0.2013 & 0.2044 & 0.5621 & 0.9202 & 0.8346 & 0.7806 & 0.7830 & 0.8661 & 0.9263 & 0.0354 & 0.8629 & 0.7630 & 0.8760 & 0.6752 \\
\hline Bank 8 & 0.3396 & 0.8750 & 1.0000 & 0.0738 & 0.0630 & 0.9602 & 0.4708 & 0.1058 & 0.6712 & 0.3019 & 0.8135 & 0.5831 & 0.5301 & 0.9476 & 0.8854 & 0.9278 & 1.0000 \\
\hline Bank 9 & 0.4652 & 0.7065 & 0.5681 & 0.4765 & 0.4928 & 0.6510 & 0.0000 & 0.0000 & 0.0000 & 0.7547 & 0.0000 & 0.6706 & & 0.7808 & 0.8185 & 0.6994 & 0.7615 \\
\hline $\begin{array}{c}\text { Bank } \\
10\end{array}$ & 0.4866 & 0.7268 & 0.6712 & 0.1208 & 0.1178 & 0.8025 & 0.8624 & 0.3194 & 0.8447 & 0.0000 & 0.6722 & 0.0000 & 0.4319 & 0.9495 & 0.8069 & 0.9558 & 0.5239 \\
\hline $\begin{array}{c}\text { Bank } \\
11\end{array}$ & 0.2219 & 0.6439 & 0.0000 & 0.5638 & 0.5830 & 0.6738 & 0.8167 & 0.8136 & 0.5325 & 0.7736 & 0.8453 & 0.6964 & 0.2057 & 0.9537 & 0.6128 & 0.9326 & 0.7380 \\
\hline $\begin{array}{c}\text { Bank } \\
12\end{array}$ & 0.3075 & 0.9974 & 0.7248 & 0.4228 & 0.4027 & 1.0000 & 0.5652 & 0.3026 & 0.9587 & 0.4717 & 0.8570 & 0.4370 & 0.0000 & 0.9294 & 0.7662 & 0.9356 & 0.5780 \\
\hline $\begin{array}{c}\text { Bank } \\
13 \\
\end{array}$ & 0.7914 & 0.4799 & 0.4363 & 0.3356 & 0.3551 & 0.4851 & 0.8089 & 0.3749 & 0.5129 & 0.1792 & 0.9347 & 0.1959 & 0.4987 & 0.8978 & 0.8302 & 0.8909 & 0.7011 \\
\hline $\begin{array}{c}\text { Bank } \\
14\end{array}$ & 0.9893 & 0.3138 & 0.0300 & 0.3221 & 0.3589 & 0.1442 & 0.9714 & 0.7257 & 0.5584 & 0.5377 & 0.3768 & 0.5632 & 0.4944 & 0.7139 & 0.8358 & 0.7498 & 0.1020 \\
\hline $\begin{array}{c}\text { Bank } \\
15\end{array}$ & 0.9091 & 0.7252 & 0.5773 & 0.8591 & 0.8798 & 0.3926 & 1.0000 & 0.8471 & 0.3192 & 0.7736 & 0.7196 & 0.3998 & 1.0000 & 0.0000 & 0.0000 & 0.0000 & 0.8630 \\
\hline $\begin{array}{c}\text { Bank } \\
16 \\
\end{array}$ & 0.7594 & 0.3800 & 0.5387 & 0.4228 & 0.4629 & 0.4947 & 0.8879 & 0.4115 & 0.4176 & 0.3868 & 0.5970 & 0.6606 & 0.2967 & 0.8692 & 0.8601 & 0.8614 & 0.0000 \\
\hline $\begin{array}{c}\text { Bank } \\
17\end{array}$ & 0.6257 & 0.0000 & 0.3507 & 0.4161 & 0.4887 & 0.2300 & 0.8959 & 0.8314 & 0.4399 & 0.7264 & 0.7895 & 0.5976 & 0.0047 & 0.8663 & 0.8936 & 0.8848 & 0.6169 \\
\hline
\end{tabular}

Table 18 Absolute differences for the $1^{\text {st }}$ financial year 


\begin{tabular}{|c|c|c|c|c|c|c|c|c|c|c|c|c|c|c|c|c|c|}
\hline \multirow{2}{*}{ Bank } & \multicolumn{3}{|c|}{ CA } & \multicolumn{3}{|c|}{$\mathbf{A Q}$} & \multicolumn{3}{|c|}{ ME } & \multicolumn{4}{|c|}{ EQ } & \multicolumn{4}{|c|}{ LI } \\
\hline & CA1 & CA2 & CA3 & AQ1 & AQ2 & AQ3 & ME1 & ME2 & ME3 & EQ1 & EQ2 & EQ3 & EQ4 & LI1 & LI2 & LI3 & LI4 \\
\hline $\begin{array}{c}\text { Bank } \\
18\end{array}$ & 0.4465 & 0.8623 & 0.4319 & 1.0000 & 1.0000 & 0.5887 & 0.7777 & 0.8105 & 1.0000 & 0.8208 & 0.8273 & 0.6653 & 0.0188 & 0.8911 & 0.5240 & 0.9168 & 0.2439 \\
\hline $\begin{array}{c}\text { Bank } \\
19 \\
\end{array}$ & 0.6497 & 0.4814 & 0.5547 & 0.5638 & 0.6067 & 0.4474 & 0.7935 & 0.4115 & 0.6614 & 0.4528 & 0.8877 & 0.5550 & 0.4112 & 0.8018 & 0.7783 & 0.8259 & 0.6897 \\
\hline $\begin{array}{c}\text { Bank } \\
20\end{array}$ & 0.6230 & 1.0000 & 0.7560 & 0.7181 & 0.6926 & 0.8568 & 0.9050 & 0.8848 & 0.9716 & 0.8208 & 0.6125 & 0.6499 & 0.1985 & 0.8721 & 0.8216 & 0.8888 & 0.8850 \\
\hline
\end{tabular}

\section{Maximum and minimum absolute differences}

The maximum ( $\Delta \max )$ and the minimum $(\Delta \min )$ differences are found from the absolute difference of the compared series and the referential series.

$$
\Delta \max =1.00 ; \Delta \min =0.00 ;
$$

\section{Grey relation coefficient}

Grey relational coefficient $\xi$ is determined from the following equation as discussed in step 9 of section 3.6

$$
\xi_{i}(j)=\frac{\Delta \min +p \Delta \max }{\Delta x_{i}(j)+p \Delta \max }
$$

\section{Model Calculation:}

For example for bank3 and ME1

$\Delta \max =1.00 ; \Delta \min =0.00 ; p=0.5 ; \Delta x_{i}(j)=0.6803$ (from absolute differences table)

$$
\xi_{i}(j)=\frac{0+0.5 * 1}{0.6803+0.5 * 1}=0.4236
$$

Gray correlation coefficient $\left(\xi_{i j)}\right)$ : Maximum and minimum absolute differences are found as discussed in step-4.2.2 to 4.2.3 in methodology. The grey relation coefficient is determined

\begin{tabular}{|c|c|c|c|c|c|c|c|c|c|c|c|c|c|c|c|c|c|}
\hline \multirow{2}{*}{ Banks } & \multicolumn{3}{|c|}{ CA } & \multicolumn{3}{|c|}{$\mathbf{A Q}$} & \multicolumn{3}{|c|}{ ME } & \multicolumn{4}{|c|}{ HQ } & \multicolumn{4}{|c|}{ LI } \\
\hline & CA1 & CA2 & CA3 & $\mathrm{AOl}$ & A 02 & $\mathrm{~A} 03$ & ME1 & ME 2 & ME 3 & EOl & E02 & EOS & E04 & LI1 & LI2 & LB & LI4 \\
\hline Bank 1 & 0.4359 & 0.4100 & 0.4977 & 0.6287 & 0.6274 & 0.3836 & 0.3902 & 0.4773 & 0.3699 & 0.5579 & 0.3902 & 0.5364 & 0.5461 & 0.3368 & 0.4015 & 0.3365 & 0.3378 \\
\hline \begin{tabular}{|c|} 
Bank \\
2 \\
\end{tabular} & 0.6516 & 0.6268 & 0.7958 & 0.9613 & 0.9360 & 0.7006 & 0.4101 & 0.6197 & 0.4973 & 0.7571 & 0.4204 & 0.6188 & 0.6497 & 0.3643 & 0.3742 & 0.3625 & 0.4600 \\
\hline $\begin{array}{c}\text { Bank } \\
3 \\
\end{array}$ & 0.6850 & 0.4993 & 0.5288 & 1.0000 & 1.0000 & 1.0000 & 0.4236 & 0.8370 & 0.4363 & 0.7260 & 0.3431 & 0.5118 & 0.5261 & 0.3429 & 0.3333 & 0.3435 & 0.4073 \\
\hline $\begin{array}{c}\text { Bank } \\
4 \\
\end{array}$ & 0.3681 & 0.3686 & 0.4899 & 0.5709 & 0.5735 & 0.5434 & 0.4360 & 0.4545 & 0.3744 & 0.4274 & 0.3333 & 0.4037 & 0.5623 & 0.3560 & 0.4216 & 0.3548 & 0.6196 \\
\hline $\begin{array}{c}\text { Bank } \\
5 \\
\end{array}$ & 0.4795 & 0.3897 & 0.5159 & 0.4343 & 0.4320 & 0.3621 & 0.3506 & 0.3333 & 0.3579 & 0.3333 & 0.4572 & 0.3333 & 0.7672 & 0.3333 & 0.4146 & 0.3333 & 0.3342 \\
\hline $\begin{array}{c}\text { Bank } \\
6 \\
\end{array}$ & 1.0000 & 0.4522 & 0.5613 & 0.4974 & 0.4865 & 0.5202 & 0.4172 & 0.6875 & 0.3852 & 0.8281 & 0.3448 & 0.4708 & 0.5561 & 0.3634 & 0.3777 & 0.3580 & 0.4206 \\
\hline $\begin{array}{c}\text { Bank } \\
7 \\
\end{array}$ & 0.3333 & 0.4084 & 0.6138 & 0.7129 & 0.7098 & 0.4708 & 0.3521 & 0.3747 & 0.3904 & 0.3897 & 0.3660 & 0.3506 & 0.9339 & 0.3669 & 0.3959 & 0.3634 & 0.4255 \\
\hline $\begin{array}{c}\text { Bank } \\
8 \\
\end{array}$ & 0.5955 & 0.3636 & 0.3333 & 0.8713 & 0.8880 & 0.3424 & 0.5151 & 0.8254 & 0.4269 & 0.6235 & 0.3807 & 0.4616 & 0.4854 & 0.3454 & 0.3609 & 0.3502 & 0.3333 \\
\hline $\begin{array}{c}\text { Bank } \\
9\end{array}$ & 0.5180 & 0.4144 & 0.4681 & 0.5120 & 0.5036 & 0.4344 & 1.0000 & 1.0000 & 1.0000 & 0.3985 & 1.0000 & 0.4271 & 0.5976 & 0.3904 & 0.3792 & 0.4169 & 0.3963 \\
\hline $\begin{array}{c}\text { Bank } \\
10 \\
\end{array}$ & 0.5068 & 0.4076 & 0.4269 & 0.8054 & 0.8094 & 0.3839 & 0.3670 & 0.6102 & 0.3718 & 1.0000 & 0.4266 & 1.0000 & 0.5365 & 0.3449 & 0.3826 & 0.3434 & 0.4883 \\
\hline $\begin{array}{c}\text { Bank } \\
11\end{array}$ & 0.6926 & 0.4371 & 1.0000 & 0.4700 & 0.4617 & 0.4260 & 0.3797 & 0.3806 & 0.4842 & 0.3926 & 0.3717 & 0.4179 & 0.7085 & 0.3440 & 0.4493 & 0.3490 & 0.4039 \\
\hline
\end{tabular}
as discussed in step-4.2.4 and are presented in Table-19.

Table 19 Grey relation coefficients for the $1^{\text {st }}$ financial year 
Financial Performance Ranking of Nationalized Banks Through Integrated Ahm-Gra-Dea Method

\begin{tabular}{|c|c|c|c|c|c|c|c|c|c|c|c|c|c|c|c|c|c|}
\hline \multirow{2}{*}{ Banks } & \multicolumn{3}{|c|}{ CA } & \multicolumn{3}{|c|}{ AQ } & \multicolumn{3}{|c|}{ ME } & \multicolumn{4}{|c|}{ HQ } & \multicolumn{4}{|c|}{ LI } \\
\hline & CA1 & CA2 & CA3 & $\mathrm{AOl}$ & A 02 & A03 & ME1 & ME 2 & ME 3 & EOl & E02 & EOS & E04 & LI1 & LI2 & LB & LI4 \\
\hline & .6192 & 0.3339 & 0.4082 & 5418 & 0.5539 & 0.3333 & 0.4694 & 0.6230 & 0.3428 & 0.5146 & 0.3685 & 0.5336 & 1.0000 & 0.3498 & 0.3949 & 0.3483 & 0.4638 \\
\hline & 3872 & 0.5103 & 0.5340 & 0.5984 & 0.5847 & 0.5076 & 0.3820 & 0.5715 & 0.4936 & 0.7361 & 0.3485 & 0.7185 & 0.5006 & 0.3577 & 0.3759 & 0.3595 & 0.4163 \\
\hline & 3357 & 0.6144 & 0.9434 & 0.6082 & 0.5822 & 0.7761 & 0.3398 & 0.4079 & 0.4724 & 0.4818 & 0.5703 & 0.4703 & 0.5028 & 0.4119 & 0.3743 & 0.4001 & 0.8306 \\
\hline & 0.3548 & 0.4081 & 0.4641 & 0.3679 & 0.3624 & 0.5602 & 0.3333 & 0.3712 & 0.6103 & 0.3926 & 0.4100 & 0.5557 & 0.3333 & 1.0000 & 1.0000 & 1.0000 & 0.3668 \\
\hline & 0.3970 & 0.5682 & 0.4814 & 0.5418 & 0.5193 & 0.5027 & 0.3602 & 0.5485 & 0.5449 & 0.5638 & 0.4558 & 0.4308 & 0.6276 & 0.3652 & 0.3676 & 0.3673 & 1.0000 \\
\hline $\begin{array}{c}\text { Bank } \\
17\end{array}$ & 0.4442 & 1.0000 & 0.5877 & 5458 & 0.5057 & 0.6850 & 0.3582 & 0.3755 & 0.5320 & 0.4077 & 0.3878 & 0.4555 & 0.9906 & 0.3660 & 0.3588 & 0.3611 & 0.4477 \\
\hline $\begin{array}{c}\text { Bank } \\
18 \\
\end{array}$ & 0.5282 & 0.3670 & 0.5365 & 0.3333 & 0.3333 & 0.4593 & 0.3913 & 0.3815 & 0.3333 & 0.3786 & 0.3767 & 0.4291 & 0.9637 & 0.3594 & 0.4883 & 0.3529 & 0.6721 \\
\hline & 0.4349 & 0.5095 & 0.4741 & 0.4700 & 0.4518 & 0.5278 & 0.3865 & 0.5485 & 0.4305 & 0.5248 & 0.3603 & 0.4739 & 0.5487 & 0.3841 & 0.3911 & 0.3771 & 0.4203 \\
\hline $\begin{array}{c}\text { Bank } \\
20\end{array}$ & 0.4452 & 0.3333 & 0.3981 & 0.4105 & 0.4193 & 0.3685 & 0.3559 & 0.3611 & 0.3398 & 0.3786 & 0.4494 & 0.4348 & 0.7158 & 0.3644 & 0.3783 & 0.3600 & 0.3610 \\
\hline
\end{tabular}

\subsection{Financial soundness ranking of banks}

Optimistic grey relation grade of the banks are determined by solving the linear programming problem as discussed in step-4.3 using grey relation coefficient. Lingo code is developed for linear programming problem and is solved through LINGO 8.0 solver. Similarly, pessimistic grey relation grade of the banks are determined by solving the linear programming problem as discussed in step-4.3. From the optimistic and pessimistic grades of the banks, normalized grey relation grade is calculated and the financial soundness of the banks is ranked. Financial soundness of banks for the $1^{\text {st }}$ financial year is shown in Table-20.

Table 20 Financial soundness ranking of banks for the $1^{\text {st }}$ financial year

\begin{tabular}{|c|c|c|c|c|c|c|c|c|c|}
\hline Bank & $\boldsymbol{\Gamma}_{\boldsymbol{i}}$ & $\boldsymbol{\Gamma}_{\boldsymbol{i}}$ & $\Delta(\boldsymbol{\beta})$ & $\boldsymbol{R a n k}$ & Bank & $\boldsymbol{\Gamma}_{\boldsymbol{i}}$ & $\boldsymbol{\Gamma}_{\boldsymbol{i}}^{\prime}$ & $\Delta(\boldsymbol{\beta})$ & Rank \\
\hline Bank 1 & 0.7901 & 1.0966 & 0.3152 & 9 & Bank 11 & 0.7309 & 1.0374 & 0.1220 & 17 \\
\hline Bank 2 & 0.9412 & 1.2477 & 0.8083 & 3 & Bank 12 & 0.8058 & 1.1122 & 0.3662 & 8 \\
\hline Bank 3 & 0.9744 & 1.2809 & 0.9165 & 2 & Bank 13 & 0.8202 & 1.1267 & 0.4133 & 7 \\
\hline Bank 4 & 0.7690 & 1.0755 & 0.2464 & 13 & Bank 14 & 0.7881 & 1.0946 & 0.3087 & 10 \\
\hline Bank 5 & 0.6935 & 1.0000 & 0.0000 & 20 & Bank 15 & 0.7670 & 1.0735 & 0.2398 & 14 \\
\hline Bank 6 & 0.8266 & 1.1331 & 0.4344 & 6 & Bank 16 & 0.7844 & 1.0909 & 0.2966 & 11 \\
\hline Bank 7 & 0.7748 & 1.0812 & 0.2651 & 12 & Bank 17 & 0.7573 & 1.0638 & 0.2081 & 16 \\
\hline Bank 8 & 0.9273 & 1.2338 & 0.7628 & 4 & Bank 18 & 0.6966 & 1.0030 & 0.0099 & 19 \\
\hline Bank 9 & 1.0000 & 1.3065 & 1.0000 & 1 & Bank 19 & 0.7608 & 1.0673 & 0.2196 & 15 \\
\hline Bank 10 & 0.9080 & 1.2144 & 0.6997 & 5 & Bank 20 & 0.6989 & 1.0054 & 0.0177 & 18 \\
\hline
\end{tabular}

In the proposed AHM-GRA-DEA integrated method, financial soundness ranking of the banks is made according to the normal grey relational degree. From table **, it is observed that Bank 9 ranks first with its degree of 1.000, followed by Bank 2 and Bank 12 with the degree of 0.9189 and 0.9143 , respectively. Last rank is obtained with Bank 20 with a grey relation degree in 0.0000 .

Similarly ranking of the banks through the proposed integrated method is determined for remaining financial years and the financial soundness of banks for $2^{\text {nd }}$ financial year to $5^{\text {th }}$ financial year is shown in the Table-21 to Table- 24 . 
Table 21 Financial soundness ranking of banks for $2^{\text {nd }}$ financial year

\begin{tabular}{|c|c|c|c|c|}
\hline \multirow{2}{*}{ Bank } & \multicolumn{4}{|c|}{ Integrated AHM- GRA-DEA } \\
\cline { 2 - 5 } & $\Gamma_{i}$ & $\boldsymbol{\Gamma}_{\boldsymbol{i}}$ & $\Delta_{i}(\beta)$ & Rank \\
\hline Bank 1 & 0.8233 & 1.1768 & 0.5001 & 6 \\
\hline Bank 2 & 0.8811 & 1.2346 & 0.6637 & 4 \\
\hline Bank 3 & 0.9872 & 1.3408 & 0.9638 & 2 \\
\hline Bank 4 & 0.7544 & 1.1079 & 0.3052 & 13 \\
\hline Bank 5 & 0.7824 & 1.1359 & 0.3845 & 10 \\
\hline Bank 6 & 0.7766 & 1.1301 & 0.3680 & 11 \\
\hline Bank 7 & 0.6465 & 1.0000 & 0.0000 & 20 \\
\hline Bank 8 & 0.8883 & 1.2418 & 0.6840 & 3 \\
\hline Bank 9 & 0.8337 & 1.1872 & 0.5295 & 5 \\
\hline Bank 10 & 1.0000 & 1.3535 & 1.0000 & 1 \\
\hline Bank 11 & 0.7434 & 1.0970 & 0.2743 & 14 \\
\hline Bank 12 & 0.7174 & 1.0710 & 0.2007 & 17 \\
\hline Bank 13 & 0.8011 & 1.1546 & 0.4374 & 9 \\
\hline Bank 14 & 0.7690 & 1.1225 & 0.3466 & 12 \\
\hline Bank 15 & 0.8171 & 1.1707 & 0.4828 & 7 \\
\hline Bank 16 & 0.7392 & 1.0928 & 0.2624 & 16 \\
\hline Bank 17 & 0.8015 & 1.1551 & 0.4387 & 8 \\
\hline Bank 18 & 0.7173 & 1.0708 & 0.2003 & 18 \\
\hline Bank 19 & 0.7399 & 1.0934 & 0.2642 & 15 \\
\hline Bank 20 & 0.7169 & 1.0705 & 0.1993 & 19 \\
\hline
\end{tabular}

Table 22 Financial soundness ranking of banks for $3^{\text {rd }}$ financial year

\begin{tabular}{|c|c|c|c|c|}
\hline \multirow{2}{*}{ Bank } & \multicolumn{4}{|c|}{ Integrated AHM-GRA-DEA } \\
\cline { 2 - 5 } & $\Gamma_{i}$ & $\boldsymbol{\Gamma}_{\boldsymbol{i}}$ & $\Delta_{i}(\beta)$ & Rank \\
\hline Bank 1 & 0.6895 & 1.0236 & 0.0707 & 18 \\
\hline Bank 2 & 0.7855 & 1.1196 & 0.3580 & 7 \\
\hline Bank 3 & 0.8407 & 1.1748 & 0.5232 & 5 \\
\hline Bank 4 & 0.7655 & 1.0997 & 0.2983 & 12 \\
\hline Bank 5 & 0.8815 & 1.2156 & 0.6454 & 3 \\
\hline Bank 6 & 0.7407 & 1.0748 & 0.2239 & 15 \\
\hline Bank 7 & 0.6759 & 1.0100 & 0.0299 & 19 \\
\hline Bank 8 & 0.8621 & 1.1962 & 0.5873 & 4 \\
\hline Bank 9 & 1.0000 & 1.3341 & 1.0000 & 1 \\
\hline Bank 10 & 0.7806 & 1.1147 & 0.3433 & 9 \\
\hline Bank 11 & 0.6965 & 1.0306 & 0.0916 & 17 \\
\hline Bank 12 & 0.7450 & 1.0791 & 0.2368 & 14 \\
\hline Bank 13 & 0.7807 & 1.1148 & 0.3437 & 8 \\
\hline Bank 14 & 0.8072 & 1.1414 & 0.4231 & 6 \\
\hline Bank 15 & 0.7759 & 1.1101 & 0.3294 & 10 \\
\hline Bank 16 & 0.7675 & 1.1017 & 0.3042 & 11 \\
\hline Bank 17 & 0.9023 & 1.2364 & 0.7076 & 2 \\
\hline Bank 18 & 0.7006 & 1.0347 & 0.1039 & 16 \\
\hline Bank 19 & 0.7630 & 1.0972 & 0.2908 & 13 \\
\hline Bank 20 & 0.6659 & 1.0000 & 0.0000 & 20 \\
\hline
\end{tabular}


Financial Performance Ranking of Nationalized Banks Through Integrated Ahm-Gra-Dea Method

Table 23 Financial soundness ranking of banks for $4^{\text {th }}$ financial year

\begin{tabular}{|c|c|c|c|c|}
\hline \multirow{2}{*}{ Bank } & \multicolumn{4}{|c|}{ Integrated AHM- GRA-DEA } \\
\cline { 2 - 5 } & $\Gamma_{i}$ & $\boldsymbol{\Gamma}_{\boldsymbol{i}}$ & $\Delta_{i}(\beta)$ & Rank \\
\hline Bank 1 & 0.7651 & 1.0412 & 0.1493 & 19 \\
\hline Bank 2 & 0.7860 & 1.0620 & 0.2247 & 15 \\
\hline Bank 3 & 0.9749 & 1.2510 & 0.9091 & 2 \\
\hline Bank 4 & 0.9256 & 1.2016 & 0.7304 & 4 \\
\hline Bank 5 & 0.8400 & 1.1160 & 0.4203 & 11 \\
\hline Bank 6 & 0.8525 & 1.1285 & 0.4656 & 9 \\
\hline Bank 7 & 0.7239 & 1.0000 & 0.0000 & 20 \\
\hline Bank 8 & 0.8638 & 1.1398 & 0.5066 & 7 \\
\hline Bank 9 & 1.0000 & 1.2761 & 1.0000 & 1 \\
\hline Bank 10 & 0.8548 & 1.1308 & 0.4739 & 8 \\
\hline Bank 11 & 0.7676 & 1.0437 & 0.1583 & 18 \\
\hline Bank 12 & 0.8387 & 1.1148 & 0.4158 & 12 \\
\hline Bank 13 & 0.8297 & 1.1058 & 0.3831 & 14 \\
\hline Bank 14 & 0.9230 & 1.1991 & 0.7212 & 5 \\
\hline Bank 15 & 0.8400 & 1.1161 & 0.4205 & 10 \\
\hline Bank 16 & 0.7815 & 1.0576 & 0.2085 & 16 \\
\hline Bank 17 & 0.9282 & 1.2043 & 0.7399 & 3 \\
\hline Bank 18 & 0.8835 & 1.1596 & 0.5780 & 6 \\
\hline Bank 19 & 0.8338 & 1.1098 & 0.3978 & 13 \\
\hline Bank 20 & 0.7712 & 1.0473 & 0.1712 & 17 \\
\hline
\end{tabular}

Table 24 Financial soundness ranking of banks for $5^{\text {th }}$ financial year

\begin{tabular}{|c|c|c|c|c|}
\hline \multirow{2}{*}{ Bank } & \multicolumn{4}{|c|}{ Integrated AHM-GRA-DEA } \\
\cline { 2 - 5 } & $\Gamma_{i}$ & $\boldsymbol{\Gamma}_{\boldsymbol{i}}^{\prime}$ & $\Delta_{i}(\beta)$ & Rank \\
\hline Bank 1 & 0.7857 & 1.078252 & 0.2675 & 18 \\
\hline Bank 2 & 0.8450 & 1.1376 & 0.4703 & 9 \\
\hline Bank 3 & 0.9476 & 1.2401 & 0.8208 & 2 \\
\hline Bank 4 & 0.8492 & 1.1417 & 0.4845 & 8 \\
\hline Bank 5 & 0.7993 & 1.0919 & 0.3141 & 15 \\
\hline Bank 6 & 0.8375 & 1.1300 & 0.4444 & 11 \\
\hline Bank 7 & 0.7660 & 1.0585 & 0.2001 & 19 \\
\hline Bank 8 & 0.8341 & 1.1266 & 0.4329 & 12 \\
\hline Bank 9 & 0.9400 & 1.2326 & 0.7951 & 3 \\
\hline Bank 10 & 0.8601 & 1.1527 & 0.5219 & 7 \\
\hline Bank 11 & 0.7075 & 1.0000 & 0.0000 & 20 \\
\hline Bank 12 & 0.8133 & 1.1059 & 0.3619 & 14 \\
\hline Bank 13 & 0.7951 & 1.0877 & 0.2996 & 16 \\
\hline Bank 14 & 1.0000 & 1.2925 & 1.0000 & 1 \\
\hline Bank 15 & 0.9148 & 1.2074 & 0.7088 & 5 \\
\hline Bank 16 & 0.8818 & 1.1744 & 0.5961 & 6 \\
\hline Bank 17 & 0.9227 & 1.2152 & 0.7357 & 4 \\
\hline Bank 18 & 0.7876 & 1.0801 & 0.2740 & 17 \\
\hline Bank 19 & 0.8404 & 1.1329 & 0.4543 & 10 \\
\hline Bank 20 & 0.8179 & 1.1105 & 0.3776 & 13 \\
\hline
\end{tabular}


Table 25 Financial soundness ranking of banks for

$1^{\text {st }}$ financial year to $5^{\text {th }}$ financial year

\begin{tabular}{|c|c|c|c|c|c|c|}
\hline \multirow{2}{*}{ Bank } & \multicolumn{5}{|c|}{ Financial years } & \multirow{2}{*}{$\begin{array}{c}\text { Average } \\
\text { rank }\end{array}$} \\
\hline & $1^{\text {st }}$ year & $2^{\text {nd }}$ year & $3^{\text {rd }}$ year & $4^{\text {th }}$ year & $5^{\text {th }}$ year & \\
\hline Bank 1 & 9 & 6 & 18 & 19 & 18 & 16 \\
\hline Bank 2 & 3 & 4 & 7 & 15 & 9 & 7 \\
\hline Bank 3 & 2 & 2 & 5 & 2 & 2 & 2 \\
\hline Bank 4 & 13 & 13 & 12 & 4 & 8 & 9 \\
\hline Bank 5 & 20 & 10 & 3 & 11 & 15 & 12 \\
\hline Bank 6 & 6 & 11 & 15 & 9 & 11 & 10 \\
\hline Bank 7 & 12 & 20 & 19 & 20 & 19 & 20 \\
\hline Bank 8 & 4 & 3 & 4 & 7 & 12 & 3 \\
\hline Bank 9 & 1 & 5 & 1 & 1 & 3 & 1 \\
\hline Bank 10 & 5 & 1 & 9 & 8 & 7 & 4 \\
\hline Bank 11 & 17 & 14 & 17 & 18 & 20 & 18 \\
\hline Bank 12 & 8 & 17 & 14 & 12 & 14 & 14 \\
\hline Bank 13 & 7 & 9 & 8 & 14 & 16 & 11 \\
\hline Bank 14 & 10 & 12 & 6 & 5 & 1 & 6 \\
\hline Bank 15 & 14 & 7 & 10 & 10 & 5 & 8 \\
\hline Bank 16 & 11 & 16 & 11 & 16 & 6 & 13 \\
\hline Bank 17 & 16 & 8 & 2 & 3 & 4 & 5 \\
\hline Bank 18 & 19 & 18 & 16 & 6 & 17 & 17 \\
\hline Bank 19 & 15 & 15 & 13 & 13 & 10 & 15 \\
\hline Bank 20 & 18 & 19 & 20 & 17 & 13 & 19 \\
\hline
\end{tabular}

Average ranking is made by considering the average rank of the banks during 5 financial years. Average ranking of the banks is shown in the Table-25. From the results, it is observed that Bank 9 is obtained first rank on an average. Bank 9 obtained financial soundness rankings of $1^{\text {st }}, 5^{\text {th }}, 1^{\text {st }}, 1^{\text {st }}$ and $3^{\text {rd }}$ respectively in the years in $1^{\text {st }}$ year, $2^{\text {nd }}$ year, $3^{\text {rd }}$ year, $4^{\text {th }}$ year and $5^{\text {th }}$ year respectively. Bank 3 is ranked as second having ranks $2^{\text {nd }}, 2^{\text {nd }}, 5^{\text {th }}, 2^{\text {nd }}$ and $2^{\text {nd }}$ in $1^{\text {st }}$ year, $2^{\text {nd }}$ year, $3^{\text {rd }}$ year, $4^{\text {th }}$ year and $5^{\text {th }}$ year respectively. Bank 7 is positioned in the last rank since the bank obtained poor average ranks of $12^{\text {th }}, 20^{\text {th }}, 19^{\text {th }}, 20^{\text {th }}$ and $19^{\text {th }}$ rank in $1^{\text {st }}$ year, $2^{\text {nd }}$ year, $3^{\text {rd }}$ year, $4^{\text {th }}$ year and $5^{\text {th }}$ year respectively.

\section{CONCLUDING REMARKS}

Due to radical changes in the banking sector in the recent years, the banks all around the world have improved their supervision quality and techniques. In evaluating the function of the banks, many of the developed countries are now following uniform financial rating system (CAMEL RATING). CAMEL rating system does not consider the relative weights of the performance dimensions and their enablers while ranking of the banks. In this thesis, five performance dimensions and seventeen enablers are considered to rank the banks through integrated method AHM-GRA-DEA. The relative weights of the performance dimensions and their enablers are determined through AHM. Grey relation coefficient of the banks is determined using grey relation analysis. These coefficients are used in the optimistic and pessimistic additive DEA models to arrive the normalized compromise grade. Then the banks are ranked according to the descending order of the normalized compromise grade. Choosing a priori weights of attributes, using AHM, in the proposed models is an important matter. Equal weight assumption might not be acceptable for decision-makers in selecting the alternatives based on the multiple criteria. 
However, one of the problems that may occur in practical situations is the difficulty of gathering the different views from some experts for use in AHM. This restricts us in deriving the priority weights of attributes, which further should be used in the proposed additive DEA-based GRA models. Future research may utilize several other techniques to investigate the casual relationships among performance evaluation indices of different methods to objectively build strategy maps. Finally, exploring more cases and conducting more empirical studies are recommended to further validate the usefulness of the proposed performance evaluation models.

\section{REFERENCES}

[1] Akbar Alem Tabriz, Aliasghar Aliakbarzadeh,"Performance Evaluation and Ranking the Branches of Bank using FAHP and TOPSIS Case study", International Journal of Academic Research in Business and Social Sciences, Vol. 4, No. 12, 2014, pp.199-217

[2] Zeliha Kaygisız Ertuğ and Nuray Girginer, "Evaluation of banks' commercial credit applications using the analytic hierarchy process and Grey relational analysis: A comparison between public and private banks", South African Journal of Economic and Management Sciences, Vol 18, No. 3, 2015, pp.308-324

[3] Ahmad Aziz Putra Pratama, Does Asset Quality Matter in Relationship Between Bank Capital on Lending Growth?, International Journal of Management, 10 (5), 2019, pp. 3847.

[4] Elham Shadkam and Mehdi Bijari , "The Optimization of Bank Branches Efficiency by Means of Response Surface Method and Data Envelopment Analysis: A Case of Iran”, Journal of Asian Finance, EcoNo.mics and Business Vol. 2, No. 2, 2015, pp. 13-18

[5] Dariush Akbarian, "Ranking All DEA-Efficient DMUs Based on Cross Efficiency and Analytic Hierarchy Process Methods", Journal of Optimization, Vol. 2015, No.-110, 2015

[6] Mousa. G.A, "Financial Ratios versus Data Envelopment Analysis: The Efficiency Assessment of Banking Sector in Bahrain Bourse", International Journal of Business and Statistical Analysis, Vol.2, No.2, 2015, pp.75-86

[7] Amitabh Bhowmick and Dr. Shashi Srivastava, the Impact of Capital Adequacy Ratio under Base II on the Determinants of Profitability Ratios of Punjab National Bank. International Journal of Management, 8 (2), 2017, pp. 89-105.

[8] Arora. S, and Kaur. S. (Aşır Özbek, "Performance Analysis of Public Banks in Turkey", International Journal of Business Management and EcoNo.mic Research, Vol.6, No.3, 2015, pp.178-186.

[9] Mehmet Ozcalici, Mete Bumin and Yucel Ayricay, "Forecasting the Rankings of Banks by Return on Assets in Turkish Banking Sector with Topsis, Fuzzy Topsis and Grey Relational Analysis Techniques", Global Journal For Research Analysis, Vol.4,No.12, 2015, pp.7779

[10] Asmita Chitnis , Omkarprasad S Vaidya , "Efficiency ranking method using DEA and TOPSIS (ERM-DT): Case of an Indian bank", Benchmarking: An International Journal, Vol. 23 No. 1, 2016, pp. 165 - 182

[11] Mohammad Rezae and Saeedeh Ketab, "Ranking the Banks through Performance Evaluation by Integrating Fuzzy AHP and TOPSIS Methods: A Study of Iranian Private Banks", International Journal of Academic Research in Accounting, Finance and Management Sciences Vol. 6, No. 3, 2016, pp. 19-30

[12] Mehdi Fallah Jelodar, "Prioritization of the Factors Affecting Bank Efficiency Using Combined Data Envelopment Analysis and Analytical Hierarchy Process Methods", Journal of Optimization,Vol. 2016, pp.1-7 